\title{
European Regional Populations: Current Trends, Future Pathways, and Policy Options
}

\section{Population des Régions Européennes: Tendances Actuelles, Développements Futurs et Options Politiques}

\author{
Philip Rees • Nicole van der Gaag • Joop de Beer • \\ Frank Heins
}

Received: 30 September 2011/Accepted: 12 July 2012/Published online: 25 September 2012

(C) Springer Science+Business Media B.V. 2012

\begin{abstract}
Europe is currently experiencing an ageing population and slowing population growth of both the total and working-age populations. These trends are likely to continue. Even though population ageing will affect all European regions, different regions will be affected in different ways. Even under favorable conditions, 35-40 \% of all NUTS2 regions will face a labor force decline. If economic conditions are poor, some regions may continue to grow, but 55-70\% of the regions will see a labor force decline by $10 \%$ or more. In most regions of Eastern Europe, the labor force may decrease by more than $30 \%$. To keep regions prosperous (maintaining competitiveness) and to avoid worse inequality (maintaining cohesion), policy-makers must find ways to cope with these challenges through new fiscal and social policies, though policies directly affecting demographic and migratory trends may also be needed.
\end{abstract}

Keywords European regional demographic development .

European migration flows - Scenarios for population development ·

Policies affecting demography · European population projections

P. Rees

School of Geography, University of Leeds, Leeds LS2 9JT, UK

e-mail: p.h.rees@leeds.ac.uk

N. van der Gaag $(\bowtie) \cdot$ J. de Beer

Netherlands Interdisciplinary Demographic Institute, P.O. Box 11650, 2502 AR Den Haag,

The Netherlands

e-mail: gaag@nidi.nl

J. de Beer

e-mail: beer@nidi.nl

F. Heins

Institute for Research on Population and Social Policies/National Research Council,

Via Palestro 32, 00185 Rome, RM, Italy

e-mail: frank.heins@irpps.cnr.it 
Résumé Actuellement, l'Europe connaît un vieillissement de sa population et un ralentissement de la croissance de sa population totale et d'âge actif. Ces tendances vont vraisemblablement se poursuivre. Bien que le vieillissement de la population concerne toutes les régions, les différentes régions vont être diversement touchées. Même dans des conditions favorables, 35 à $40 \%$ des régions NUTS devront faire face à un déclin de leur population active. Si les conditions économiques sont médiocres, certaines régions peuvent continuer se développer, mais 55 à $70 \%$ des régions connaîtront un déclin de $10 \%$ ou plus de leur population active. Dans la plupart des régions d'Europe de l'Est, la population active risque de diminuer de plus de $30 \%$. Pour que les régions restent prospères (maintien de la compétitivité) et pour que soit évité le renforcement des inégalités (maintien de la cohésion), les décideurs politiques doivent trouver des moyens pour relever ces défis par le biais de nouvelles politiques fiscales et sociales, bien que des politiques ayant une incidence directe sur les tendances démographiques et migratoires puissent être également nécessaires.

Mots-clés Croissance démographique des régions européennes .

Flux migratoires européens · Scénarios de croissance démographique ·

Politiques démographiques · Projections de population européenne

\section{Introduction}

Today's main demographic developments across Europe ${ }^{1}$ are an ageing population, a slowing down of population growth, and decreasing growth rates of the workingage population. These developments are expected to remain the most important demographic challenges in the next decades. If life expectancy continues to grow, the population aged 65 and over is expected to increase to about twice the current number. At the same time, if the size and direction of migration flows and reproductive behavior do not change, the size of the working-age population will decline considerably. Although demographic ageing and migration will affect regions all across Europe, different regions may be affected in different ways. In regions with high levels of fertility and high inflows of migrants, the effect of ageing on the size of the working-age population may be mitigated, while in regions with high outflows of young migrants, the effects of ageing may be reinforced. Generally, net flows of migrants are positive in affluent regions and negative in poor regions, which may result in increasing disparities.

Ageing and declining populations strongly influence labor markets, healthcare expenditures, and social security systems. Population and labor, therefore, are essential inputs to policy-making and medium and long-term planning, especially on a regional level. European Union (EU) regional policy came about in the early 1970s with the initiation of the legislative process to create the Regional

\footnotetext{
1 Europe throughout the paper is defined as the following set of countries: the European Union 27 Member States, the three EFTA states Iceland, Liechtenstein, and Norway, and Switzerland.
} 
Development Fund (CEC 1973). The two goals of this regional policy were to give all regions the opportunity to make optimal use of available resources and thus achieve competitiveness (efficiency), and to provide all individuals more similar standards of living (equity). In the mid-1980s, cohesion policy was introduced for countries and regions where development was lagging behind. ${ }^{2}$ The territorial dimension of cohesion policy was explicitly introduced in 2001 in the Treaty of Nice. The main idea of territorial cohesion is to contribute to European sustainable development and global competitiveness. To achieve territorial cohesion, the European territorial development debate is framed within several seminal strategies and agendas. These include the Lisbon strategy (CEC 2005), the Territorial Agenda for the EU (Ministers Responsible for Territorial Development 2007), the Commission's Green Paper on Territorial Cohesion (CEC 2008a) and the Europe 2020 discussions for smart, sustainable and inclusive growth (CEC 2008b). The enlargement of the EU to the current 27 very diverse countries has provided further arguments for European wide policies aimed at enabling all people, independently of where they live, to benefit from the opportunities created by the Union (Barca 2009).

For European-wide, supra-national policies, consistent and supra-nationally compiled regional population projections are preferred over existing, often mutually inconsistent, nationally compiled regional projections. For this reason, the European Commission regularly orders the compilation of a set of supra-national consistent regional population projections. The latest regional level projections produced by Eurostat are the EUROPOP2008 scenarios (Giannakouris 2008). These projections cover the period 2008-2030 for all NUTS2 ${ }^{3}$ regions of the 27 EU Member States (Eurostat 2008) as well as 14 statistical regions for Norway and Switzerland. Although a new set of national level population projections have been released in June 2011 (EUROPOP2010, Lanzieri 2011), corresponding regional population projections were not available in March 2012.

The EUROPOP population projections are what-if scenarios that aim to provide information about the likely future size and structure of the population. The assumptions of the EUROPOP2008 scenarios have been developed in a conceptual framework of convergence of demographic values as a result of decreasing socioeconomic and cultural differences between the Member States of the EU, Norway, and Switzerland. This set of scenarios implies a convergence of the most important demographic values in the year 2150. Fertility is assumed to converge to levels achieved by countries that are forerunners in the demographic transition, life expectancy increases are assumed to be greater for countries with lower levels of life expectancy and smaller for countries with higher levels, and migration is assumed to converge to zero net migration in 2150. Additionally, migration has been adjusted upwards if the working-age population decreases for the respective

\footnotetext{
${ }^{2}$ Cohesion is a collective commitment to ensure that the disparities in standards of living and quality of life across European Union nations and regions are reduced. Cohesion implies that the poorest regions should catch up with the richest regions in living standards.

3 NUTS stands for Nomenclature commune des unites territoriales statistiques and is a regional classification scheme for organizing harmonized statistics for countries, regions, and municipalities in Europe. The NUTS2 regions are of medium size.
} 
projection years (Giannakouris 2008). The latest regional population projections are fully consistent with the EUROPOP2008 national projections. Assumptions on fertility, mortality, and international migration used for the national population projections were made region-specific using regional scaling factors. Furthermore, assumptions were made about interregional migration. These assumptions were based on inter-NUTS2 departures and arrivals by age, sex, and region, and the total number of inter-NUTS2 migrations by region of origin and region of destination. Internal mobility and regional differences were calculated as an average of flows in recent years, depending on countries' data availability, and were assumed not to change from the recent situation (Giannakouris 2010).

While the Eurostat convergence scenario projects an overall population increase by $5 \%$ between 2008 and 2030, it also shows a considerable variation between the different regions. Between 2008 and 2030 in one out of three regions population may decline, the median age of the regions' population will increase from between 33 and 48 years in 2008 to 34-57 years in 2030 and the share of the population aged 65 years or over is expected to increase from 9-27\% to 10-37\% (Giannakouris 2010). These demographic developments and regional variations may constitute a risk for European competitiveness and territorial cohesion.

As convergence is a central concept to many EU policies, convergence is a natural conceptual framework for assumption setting in the context of the EU (Lanzieri 2009). The Eurostat convergence scenario, however, is only one of several possible population-change scenarios based on assumptions on fertility, mortality, and migration. Different policies may result in different demographic futures. The aim of this paper is to assess the effects of demographic trends and migration flows on European regions within different policy frameworks and to examine the implications for regional competitiveness and European cohesion. As it is uncertain to what extent territorial policies will be effective, we examined a number of policy scenarios based on alternative assumptions about: (1) future developments in economic trends, innovation and climate change, and (2) the implementation and effectiveness of regional cohesion policies. Scenarios in which policies will succeed in narrowing regional disparities are compared with scenarios in which well-off regions will benefit more than regions lagging behind. As a point of reference for the policy scenarios, we calculated three reference scenarios: a "status quo" and two "no migration" scenarios. The status quo scenario assumes a continuation of recent demographic regimes until 2050. The first "no migration" scenario assumes free movement within Europe, but no migration to and from the rest of the world. The second "no migration" scenario is an extreme version of "Fortress Europe", where all countries and regions are assumed to close their borders to migration, i.e., for both international and internal migration. This is a natural increase-only scenario. Although all three reference scenarios are unlikely to come true, they provide useful benchmarks and establish a base line against which the policy scenarios can be compared.

The organization of the paper is as follows. In the following section, we outline the scenario framework for the projections. Next, we discuss the methods and data used to compile the projections. We then describe the different future pathways for European regions resulting from the scenarios paying explicitly attention to 
population growth and decline, ageing, and labor force perspectives. In the final section, we reflect the different prospects for European populations, dependent on future policy and current regional positions, identifying which European regions will experience positive demographic developments and which may be confronted by unfavorable demographic developments.

\section{Alternative Demographic Scenarios Linked to Policy}

In order to understand the ways in which European populations might develop under different economic and social conditions, we discuss a set of four policy-related scenarios developed as part of a European-funded project called DEMIFER under the ESPON 2013 programme (see the Acknowledgements and De Beer et al. 2010a). We developed four alternative scenarios incorporating different bundles of policies (Rees et al. 2010a). The motivation for developing alternative scenarios was twofold. First, the effects of policies depend on future economic developments. Therefore scenarios should reflect alternative future economic developments. We examined both a future characterized by sustainable growth and a future with low economic growth and worsening environmental problems. Second, policy-makers have a choice. They may emphasize social solidarity or they may stress economic competitiveness.

Based on these motivations, the scenarios link policy bundles to demographic effects using two axes of policy variation: a Distribution-Fairness axis and an Economy-Environment axis. At one end of the Economy-Environment dimension, we envisage a situation where sustainable growth has been achieved through technical and social innovation. At the other end of the Economy-Environment dimension, we envisage a situation where the environmental challenges have not been met and growth as traditionally measured has fallen. The Distribution-Fairness dimension varies from a bundle of policies designed to achieve social solidarity at one end, to a set of policies designed to improve the operation of markets and the achievement of greater competitiveness in a global market place at the other end.

Combining the two dimensions produces four policy scenarios, which we call "Growing Social Europe" (GSE), "Expanding Market Europe" (EME), "Limited Social Europe" (LSE) and "Challenged Market Europe" (CME) (Table 1). Each of these scenarios is associated with a set of policies that we may expect to influence, to a greater or lesser degree, future patterns of mortality, fertility, and migration. The different scenarios thus assess the future impact of different developments in mortality, fertility, and migration on changes in population growth, particularly in the changes of the size of the working-age population, and on population ageing. As the growth of the labor force does not just depend on the size of the working-age population but also on the level of labor force participation rates, alternative assumptions on future changes in labor force participation rates are included in the specification of the scenarios.

The GSE scenario describes changes in population size and age structure if successful economic and environmental policies result in sustainable growth and cohesion policies are effective in reducing regional disparities. Relatively large 
Table 1 Policy scenarios for Europe

\begin{tabular}{|c|l|c|c|}
\hline \multirow{2}{*}{$\begin{array}{l}\text { ECONOMY- } \\
\text { ENVIRONMENT }\end{array}$} & $\begin{array}{l}\text { Growth enabled by } \\
\text { technical and social } \\
\text { innovation }\end{array}$ & $\begin{array}{c}\text { GROWING SOCIAL } \\
\text { EUROPE (GSE) } \\
\text { High Growth/Collectivism }\end{array}$ & $\begin{array}{c}\text { EXPANDING MARKET } \\
\text { EUROPE (EME) } \\
\text { High Growth/Individualism }\end{array}$ \\
\cline { 2 - 4 } & $\begin{array}{l}\text { Growth limited by } \\
\text { environmental } \\
\text { constraints }\end{array}$ & $\begin{array}{l}\text { LIMITED SOCIAL } \\
\text { EUROPE (LSE) } \\
\text { Low Growth/Collectivism }\end{array}$ & $\begin{array}{c}\text { CHALLENGED MARKET } \\
\text { EUROPE (CME) }\end{array}$ \\
\hline \multirow{2}{*}{ POLICY SCENARIh/Individualism } \\
EUROPE
\end{tabular}

Rees et al. (2010a)

decreases in mortality are foreseen together with relatively large increases in fertility. Migration levels will also increase significantly. For all components of growth, regional differences will decrease substantially. The EME scenario shows the demographic development if policies focus on competition in the context of sustainable economic growth. Slightly less favorable developments in mortality and fertility are assumed to go hand in hand with large increases in migration and higher regional inequalities. In times of low economic growth and growing environmental problems, the LSE scenario shows the consequences of effective cohesion policies. This future is characterized by relatively small decreases in mortality, constant fertility patterns, and declining migration levels. Regional inequalities in the drivers of population change are expected to decline, but not as much as in the GSE scenario. Finally, in times of low economic growth where environmental challenges are not met, the CME scenario shows the demographic consequences of strong competitive goals. In terms of demographic and migratory drivers, this is the least favorable scenario with only slightly decreasing mortality, declining fertility, more or less constant migration levels, and increasing regional inequalities.

Table 2 sets out a range of policies that will influence each demographic component in either a positive or a negative direction, which are represented by words in the table indicating the influence of the policy on the demographic component, either in level or in direction. The strengths of these policies will vary according to scenario and a strong effect is registered with a suitable phrase in the table. At the bottom of each panel in Table 2, where appropriate, we summarize the combined impact policies may have on regional inequalities. For example, in the mortality panel, under the GSE scenario, inequalities may fall substantially; under the EME scenario they will likely rise considerably. These are qualitative judgements, which we now justify.

The level of fertility may be affected by family-friendly policies such as subsidized day care or paid parental leave (Neyer and Anderson 2008). ExtraEuropean migration, especially from cultures that have a tradition of high fertility, 
Table 2 Policies affecting the demographic components and an assessment of their influence in each policy scenario

\begin{tabular}{|c|c|c|c|c|}
\hline Policy & GSE & EME & LSE & CME \\
\hline \multicolumn{5}{|l|}{ Fertility } \\
\hline Family/individual goals & Family & Individual & Family & Individual \\
\hline Family friendly policies & Strong & Weak & Strong & Weak \\
\hline Assisted conception & $\begin{array}{l}\text { Socially } \\
\text { supported }\end{array}$ & $\begin{array}{l}\text { Privately } \\
\text { supported }\end{array}$ & $\begin{array}{l}\text { Socially } \\
\text { supported }\end{array}$ & $\begin{array}{l}\text { Privately } \\
\text { supported }\end{array}$ \\
\hline Abortion law & Permissive & Restrictive & Permissive & Restrictive \\
\hline Extra-Europe migration & High & Low & Low & Low \\
\hline Inequalities & Reduced & Persistent & Reduced & Persistent \\
\hline \multicolumn{5}{|l|}{ Mortality } \\
\hline Smoking & Falls & Trend & Falls & Trend \\
\hline Diet/obesity & No epidemic & No epidemic & Epidemic & Epidemic \\
\hline Drinking/drug use & Falls & Trend & Falls & Trend \\
\hline Medical advances & High & High-medium & Medium-low & Low \\
\hline Inequalities & Reduced & Persistent & Reduced & Persistent \\
\hline \multicolumn{5}{|l|}{ Extra-Europe migration } \\
\hline Total level & Moderate & High & Low & Moderate \\
\hline Emigration origins & Stable & Divergent & Stable & Divergent \\
\hline Immigration destinations & Stable & Divergent & Stable & Divergent \\
\hline $\begin{array}{l}\text { Extra-Europe migration } \\
\text { policy }\end{array}$ & Free entry & Selective entry & Restricted & Moderate \\
\hline \multicolumn{5}{|l|}{ Intra-Europe migration } \\
\hline Total level & Moderate & High & Low & Moderate \\
\hline Differences out-migration & Stable & Divergent & Convergent & Divergent \\
\hline Differences in-migration & Stable & Divergent & Convergent & Divergent \\
\hline $\begin{array}{l}\text { Inter-state migration } \\
\text { policy }\end{array}$ & Restrictions & Free movement & Restrictions & Free movement \\
\hline \multicolumn{5}{|l|}{ Internal migration } \\
\hline Level of out-migration & Stable & Stable & Stable & Stable \\
\hline Relative attractiveness & Convergent & Divergent & Convergent & Divergent \\
\hline \multicolumn{5}{|l|}{ Labor force participation } \\
\hline Trends in participation & Increasing & Increasing & Decreasing & Stable \\
\hline Participation of the young & Increasing & Increasing & Decreasing & Stable \\
\hline Female participation & Friendly & Unfriendly & Friendly & Unfriendly \\
\hline Participation of the elderly & Favorable & Stressful & Favorable & Stressful \\
\hline Inequalities & Reduced & Increased & Stable & Increased \\
\hline
\end{tabular}

may have an impact on the level of fertility as well (Tromans et al. 2009). Variations in fertility rates will be highest if policies are market-oriented and economic growth is high (Kravdal 2002; Engelhardt et al. 2004). In the EME scenario, there will be pockets of regions with very high total fertility rates (TFRs) in the northern and western European countries and very low fertility rates in the southern, central, and 
eastern regions. If policies are oriented towards regional cohesion, these disparities narrow (Lanzieri 2010). The GSE scenario assumes that family-friendly social welfare policies, which boost fertility rates in the northern countries, will also be pursued in other parts of Europe.

There is much literature that establishes the links between socio-economic deprivation, poor health, and premature mortality (The Marmot Review 2010; Commission on Social Determinants of Health 2008) and there is a Europe-wide aim to decrease mortality rates and raise life expectancy through investment in healthcare services, research into disease control, and promotion of healthy lifestyles (Rees et al. 2010a, Chapter 3). In addition, policies may intervene to change lifestyle choices, such as smoking, drinking, and diet (Doll et al. 2004; McPherson et al. 2009). If policies are market-oriented and economic growth is low, there will be very large disparities between the longevity of populations in disadvantaged regions in the east and the longevity of advantaged regions in the west and north, as the CME scenario shows. The disparities are less pronounced if cohesion policies prevail. Mortality rates may be more influenced by cohesion policy interventions than by market-oriented growth interventions. Yet in addition to changing trends in mortality through prevention and better health care, it is also important to be able to fund the acute treatment and social care needs of an older population, which are most often concentrated in a few years before death. These challenges could better be met through a focus on cost-effective growth in the high economic-growth scenarios.

Massey et al. (1993) and Howe and Jackson (2005) give overviews of various theoretical frameworks for international migration. Most theories focus on push factors creating out-migration pressure in sending countries such as poverty, unemployment, and political turmoil, and pull factors emphasizing the importance of the attractiveness of receiving countries for in-migration. Jennissen (2004) gives a general overview of economic determinants of international migration and stresses the importance of labor shortages for international migration patterns in Europe in the second half of the 20th century. In the coming decades, extra-European migration will become increasingly important to compensate for Europe's ageing population and provide the labor force needed, especially in the health and social care sector. If policies are market-oriented and the economy grows strongly, extra-European immigration is expected to be very high, especially to major cities or urban agglomerations. If economic growth is high but policies focus on cohesion, this pattern is also seen, although it is not quite as strong. While a great influx of extraEuropean immigration will help many regions address demographic and labor market challenges, it will also require social policies to integrate a large group of immigrants into society as well as greater inter-state coordination in immigration policy.

The Schengen Agreement (European Commission, Home Affairs 2011) facilitates inter-country mobility. The agreement covers all EU Member States except the UK and Ireland and includes the EFTA states and Switzerland. The EU's Life Long Learning Programme (European Commission, Education and Training 2011) incorporates incentive schemes that encourage the migration of students (Erasmus Scheme) and researchers (European Commission, Research and Innovation 2011). In general, however, there are no European-wide policy actions for labor migrants. International migration will be high if economic growth is high and policies are 
market-oriented, as shown in the EME scenario. In contrast, if economic growth is low and policies focus on cohesion, international migration will be low (the LSE scenario). If high economic growth in the metropolitan centers of Europe continues, the result may be greater movement of job seekers from lagging regions of Europe into the already affluent regions.

Migration in general will tend to benefit the already affluent regions by helping to address the problems of ageing and labor force shortages, but migration out of the poorer regions will only increase regional disparities. In order to promote territorial cohesion, increasing the attractiveness of regions falling behind is just as important, or more important, than boosting the competitiveness of already vibrant regions that benefit from migration. Regional policy instruments such as the Structural Funds, Cohesion Funds and the Territorial Cooperation objective should be directed towards measures attracting and retaining younger persons in these areas and redressing the exodus from shrinking areas. Currently none of these programmes offers much direct incentive for migrants to stay in their origin regions (CEC 2008a).

High economic growth will lead to a rise in labor force participation rates. If policies are aimed at reducing regional disparities in economic growth, economically weaker regions with low activity rates will catch up and approach the higher rates of the stronger regions. If policies are market-oriented, high economic growth may lead to a general strong rise in the activity rates, but regional disparities become larger as stronger regions show higher rises. If economic growth is poor, activity rates will fall everywhere. If there are policies to ease the economic pain of the weak regions, they catch up with the strong regions. If policies assume that the market has to do the work, this works fine for the economically stronger regions but not for the economically weaker regions. Disparities grow as weaker regions have to face a steeper fall in activity rates than stronger regions. Policies can be aimed to raise labor force participation rates for young persons, women, immigrants, and older persons. Policies and attitudes towards full-time, part-time, and selfemployment will affect the size of the labor force as well. National family policy can have a fundamental influence on the labor supply of women. For example, in the Nordic countries, family and labor market policies are largely organized to facilitate the reconciliation of employment and parental responsibilities for both parents, helping to solve the work-life balance (Jaumotte 2004; Rønsen 2004; Datta Gupta et al. 2008). Policy considerations to keep older workers in the labor force include reform of pension systems and retraining of older workers. Health policies should aim to maintain a healthy older, but vital workforce. As changes in the size of the labor force are a product of changes in the size of the working-age population and labor force participation rates, policies affecting fertility, mortality, and migration will also have an impact on labor force trends.

\section{Projection Methods and Data Issues}

To compile the scenarios, we need to translate the qualitative scenarios into quantitative input parameters. In order to validate the contents of the four policy scenarios and to formulate assumptions on the effectiveness of policies associated 
with each scenario, an online expert questionnaire was designed. This questionnaire was based on a demographic expert group questionnaire developed by IIASA (Prommer and Wilson 2006) as part of the European Framework 6 MicMac project ${ }^{4}$ and adapted for use by the UK's Office for National Statistics (Shaw 2008; Rowan and Wright 2010). Participants of the ESPON open conference held at Prague in 2009 were invited to complete this web-based questionnaire. The questionnaire was completed by 61 experts, including researchers, planners and geographers, with a high level of expertise in the field of demography, public policy, or public administration. The respondents represented countries more or less evenly spread over Europe.

Table 3 sets how the qualitative scenarios of Table 2 are translated into assumptions for summary parameters (drivers), which adjust the component rates and flows to reflect the policies associated with the scenario. The quantitative assumptions are partly based on the results of the expert opinion survey and partly based on recent trends in mortality, fertility, migration, and labor force participation. The summary drivers are translated into the region-specific rates or flows prorata, using the base period estimates adjusted up or down by greater or lesser amounts, depending on the scenario. More details on the assumption setting for the different components are given below (see also Rees et al. 2010a).

The quantitative fertility assumptions refer to trends in the TFR (period). Changes in TFR not only refer to changes in the average number of children per woman but also to changes in the average age at childbirth (Sobotka 2004; Kohler et al. 2006). Between 2000 and 2008, some 25 out 31 countries in Europe experienced an increase in fertility and for six countries the rise in TFR was $20 \%$ or more (Eurostat 2011). In these northern European countries, the fertility rise was driven by a catch-up among native-born women of postponed births and by higher contributions from foreign-born women as their numbers in the reproductive ages grew. However, between 2000 and 2008, on average, fertility rates in Europe (31 countries) have increased by only $8 \%$. Postponement of childbearing followed by catching up at higher ages as witnessed in the last decade in selected countries (e.g., France, UK, and Sweden), have come to an end in several European countries as women, who had postponed childbirth when in their twenties, achieved their desired number of children in their thirties. As a result, the level of fertility is likely to be fairly stable in the future. We assume that the catch-up process has been completed in the countries in which it has been experienced in the last decade and that catch-up will not start in those countries where it has not occurred. In the policy scenarios, it is assumed that no (major) trends in the timing of fertility will happen in the future. For this reason, the distribution of standardized age-specific fertility rates is assumed to be constant.

For fertility, the quantitative assumptions are based on a mix of perceived political actions in each scenario and the expected effectiveness of these policy measures derived from the expert opinion survey. The assumed increase in TFR of 0.4 in the GSE scenario stems from the combination of an active policy to raise fertility, not only by establishing a family-friendly environment but also by policies

\footnotetext{
${ }^{4}$ www.micmac-projections.org.
} 


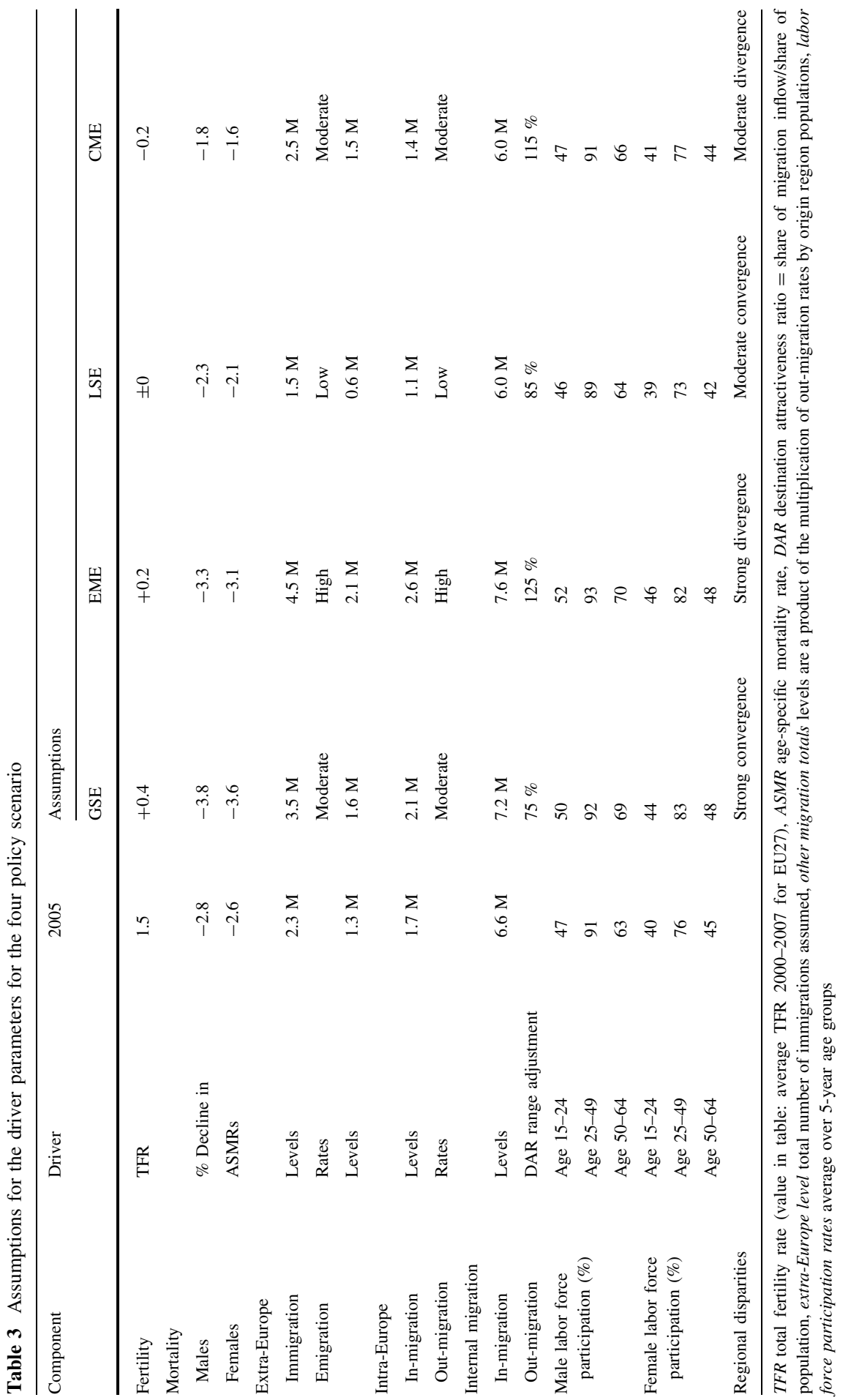


supporting assisted conception. Due to the absence of policies to stimulate fertility in general and to only modest financial contributions to support couples with fertility problems, a smaller positive effect on the TFR is apparent in the EME scenario. In the LSE scenario, positive effects of family-friendly policies are expected to be offset by liberal abortion laws, resulting in stable levels of fertility rates. In the CME scenario finally, the negative effect of the harsh economic and political climate is expected to lead to a decrease in fertility of up to 0.2 children.

National and regional mortality rates by age and sex were computed from a combination of data from the Human Mortality Database (2009) and Eurostat (2011). Assumptions have been based on the spatial pattern of mortality across Europe in the 1990s and 2000s. For regional comparisons, we used Europe standardized mortality ratios (SMRs). SMRs are more reliable than individual ageand sex-specific mortality rates (ASMRs), which are subject to reporting or estimation errors. Each SMR is re-based to a Europe-wide average for the year in question, which is assigned a value of 100. The method for projecting ASMRs for regions under the different scenarios consisted of the following steps: estimation for 1991-2006 of ASMRs for NUTS2 regions, aggregation of those estimates to give Europe ASMR estimates, computation of regional SMRs using the European ASMRs and regional populations by age and sex, application of ASMR decline rates specific to each scenario, adjustment of regional SMRs over the projection period to reflect the convergence or divergence assumed for each scenario, and finally adjustment of European ASMRs up or down using the converged or diverged regional SMRs.

The trends in ASMR reduction in the years 2001-2006 were $2.8 \%$ for men and $2.6 \%$ for women. As we assume policies favorable to mortality reduction for the GSE and EME scenarios, we assume an increased rate of mortality decline of $3.8 \%$ per annum for males and $3.6 \%$ per annum for females for the GSE scenario and of 3.3 and $3.1 \%$ for the EME scenario. Where there are fewer resources to advance improvements in health under the LSE and CME scenario, we assume an improvement of only 2.3 and $2.1 \%$ for the LSE scenario and 1.8 and $1.6 \%$ for the CME scenario for males and females, respectively. The mortality declines are assumed to operate uniformly across all ages from 2025-2030 to 2045-2050. From 2005-2010 to 2025-2030, the rates of change are interpolated between the observed rates, which differ by age, and the target rates. This method was applied in the 2006-based national population projections by ONS (2008). The faster decline rates for male ASMRs mean that life expectancies of men catch up with those of women under all scenarios.

We computed SMRs for a region by dividing total deaths in a region by the sum of the European standard ASMRs multiplied by the estimated regional populations for each year from 1991 to 2006. We modify the dispersion of regional SMRs across Europe to reflect the trends built into the scenarios. To measure the dispersion, we use the range between the 95th and the 5th percentiles because this avoids the distorting effects of extreme outliers. We compute ASMRs for regions for future periods by multiplying the estimated ASMRs for 2005-2010 (extrapolated from precise computations of the 2003-2006 ASMRs for which reliable data were available from Eurostat) by the ratio of SMR to 100 . Thus, the age-sex profile shifts in two ways: first through variation across 
scenarios in the assumed Europe-wide decline rate and second through the assumed degree of convergence or divergence in the inter-regional variation. This provides a simple but powerful combination of drivers for our policy scenarios. If the GSE scenario proves correct, a more equal Europe will result in which the laggard regions have moved towards the average and the advanced regions have less advantage than at present. The EME scenario moves regions further apart. Note that, even under the favorable trends assumed for the GSE scenario, there are still sizeable differences across Europe in the mortality experience of regional populations. Under the LSE scenario, there will be convergence in regional mortality and under the CME scenario there will be divergence.

Within the EU people can migrate between countries with a minimum of regulations. However, with respect to migration between Europe and the rest of the world, legal constraints play an important role. Given the fact that these two types of international migration happen in a completely differential judicial context, having major consequences on the amount and direction of migration flows, assumptions on these two types of migration have been made separately. The quality of migration statistics, however, varies strongly across countries and internationally consistent migration statistics are often missing. As a result, there can be considerable differences in the reported size of the same migration flow by sending and receiving countries. For example, the number of emigrants from Poland to Germany reported by the Polish statistical office is considerably lower than the number of Polish immigrants reported by Germany. As our projections are prepared simultaneously for all countries included in the scenarios we need one consistent migration matrix between all regions in the model. In order to solve this problem, we adopted intraEurope migration data from the MIMOSA project (De Beer et al. 2010b; Raymer et al. 2011). The MIMOSA project compared migration statistics reported by sending and receiving countries for 31 European countries and estimated internationally consistent migration matrices showing migration flows between these countries for the years 2002-2008. The migration flows are distinguished by country of origin, country of destination, age, and sex.

Estimates and quantitative assumptions for extra-Europe migration are based on MIMOSA estimates. Assumptions about immigration from the rest of the world are defined in absolute numbers, whereas assumptions about emigration from Europe are defined by emigration rates. In order to eliminate random fluctuations, the number of immigrants from the rest of the world for the base year of the projections was estimated by an average of the MIMOSA estimates for the years 2004-2006. This leads to a total number of 2.3 million immigrants. For the scenario period, the total number of immigrants is assumed to increase or decrease up to the year 2035 and kept constant after that year. In the GSE scenario, with a moderate increase of immigration, the number of immigrants is assumed to rise to about 3.5 million. According to the EME scenario, the increase is higher: to 4.5 million. In the LSE scenario, a fall in immigration to 1.5 million is assumed, while in the CME scenario, a slight rise to 2.5 million immigrants is assumed. Emigration from NUTS2 regions to the rest of the world is estimated on the basis of the observed regional distribution of emigration in each country provided by the MIMOSA project. These age- and sex-specific numbers are related to population numbers in the base year 2005 in order to estimate emigration rates. Based on these rates, the level of extra-Europe 
migration in 2005 amounted to 1.3 million migrants. The scenarios assume different developments in the emigration rates. In the two economic prosperous scenarios, the GSE and EME scenarios, rising emigration rates are assumed, with the latter having a steeper rise. In the less prosperous scenarios, a decline is assumed, with the LSE scenario having a larger decrease than the CME scenario. The emigration rates result in increasing numbers of emigrants compared to 2005 for the GSE and EME scenarios and decreasing numbers for the LSE and CME scenarios.

Quantitative assumptions on intra-Europe migration are based on age- and sexspecific out-migration rates, i.e., the "risk" of the population living in a European region to migrate to a region in another European country. The quantitative assumptions about future levels of out-migration rates for international migration flows between countries within Europe follow similar patterns as extra-Europe emigration: rising rates for the GSE and EME scenarios and declining rates for the LSE and CME scenarios. The resulting number of intra-Europe migrants in 2005 counted 1.7 million persons. By the end of the projection period, 2.1 and 2.6 million emigrants per annum are expected under the GSE and EME scenarios and 1.1 and 1.4 million under the LSE and CME scenarios. In order to make assumptions about the country of destination, a measure of regional attractiveness was used. Attraction factors are assumed to change up to 2035 according to the convergence or divergence assumption in each scenario. In the final step, a regional distribution model was used to assign immigrants and emigrants to NUTS2 regions. This distribution is based on data provided by Eurostat and some National Statistical Offices (NSOs), and in some cases completed with estimations. The regional distribution of emigrants from sending countries and immigrants in receiving countries is kept constant during the scenario period.

Apart from international migration, assumptions were made for internal migration. Internal migration is defined as the movement of population between NUTS2 regions within a single country. Of the 31 countries involved in the study, eight are "single-region" countries (Cyprus, Estonia, Iceland, Latvia, Liechtenstein, Lithuania, Luxembourg, and Malta) and therefore have no internal, inter-NUTS2 migration. The remaining 23 countries have internal migration for between two and 39 NUTS2 regions. Within each country's NUTS2 geographical system, there are significant spatial differences between the rates of migration being experienced. This variation and its potential to change over time due to social, economic, political, and climatic conditions were key components of the internal migration analysis. For the 23 countries concerned, a comprehensive database of statistics has been produced, created from Eurostat sources, from a number of individual NSOs and in some cases through estimation. The objective has been to derive: (1) outmigration rates for the base period of the projections (2005-2010) for each combination of origin (O), destination (D), age (A), and sex (S) within a single country, and (2) a series of assumptions to modify these base period out-migration rates over the full projection horizon (2005-2010 to 2045-2050) for each of the alternative scenarios. Using the available time series of OD migration data for each country, the most recent trend in both migration flows and migration rates has been examined. This has enabled a weighted estimate of the "average" migration rate for 2005-2010 to be derived. Migration flow data by origin, age, and sex (OAS) has been used in combination with the corresponding OD matrix to derive a full ODAS 
array of internal migration flows. Population data by NUTS2 region, age and sex (OAS) has then been combined with the ODAS migration array to produce a corresponding array of ODAS out-migration rates. The policy scenarios for internal migration are driven by adjustments to the relative attractiveness of individual destinations under varying assumptions. The attractiveness of an individual NUTS2 region is measured using a destination attractiveness ratio (DAR), which is calculated as the share of migration inflow divided by the share of population.

Within each country there is significant variation between the DAR values for NUTS2 regions. Outlying values comprise a mixture of relatively small areas plus dominant destinations within a country (for instance London in the UK). The base period DAR value for each NUTS2 region is modified over the projection period (2005-2010 to 2045-2050) leading to greater convergence or divergence in country-wide DAR values. These modified DAR values apply appropriate weights to the ODAS migration rate arrays to change the pattern and distribution of migration flows between NUTS2 regions in each country. The level of internal outmigration rates remains unchanged, with scenarios modifying only the range of values and not the scale. Internal migration fluctuates in level with the economic cycle and its housing component in particular, but we assume "ups" and "downs" cancel out over the longer term. Total internal migration flows in 2005 amounted to 6.6 million persons per annum. Due to different population developments under the four policy scenarios, by the end of the scenario period between 6.0 (LSE and CME scenarios) and 7.6 million (EME scenario) internal migrants are expected.

Finally, assumptions had to be made on labor force participation rates. The labor force is defined as the total number of people employed and those actively seeking for work. In general, fluctuations in participation rates (the sum of employment and unemployment rates) are caused by changes in participation in three broad categories of inactive persons: first, young people in education and initial training; second, older retired or disabled persons and third, women who have left the labor market after giving birth. The assumptions on labor force participation are predominantly formulated in terms of developments in these three categories. The results of the expert survey showed that most governments are trying to increase labor force participation. The general expectation is that policies to raise female participation can be quite effective. To a lesser extent, the same applies to participation of the elderly. The experts were less optimistic as far as raising participation of youngsters was concerned. In the GSE scenario, labor force participation rates will increase in all age groups. Participation rates of males in the prime working ages, however, show only small increases, as current rates already are very high. In the EME scenario, labor force participation rates will even increase more, but less policy measures are needed as a significant rise in labor demand is expected related to rather favorable economic developments. In the LSE scenario, participation is declining as a result of adverse economic developments. While males in the prime working ages will only experience a small decrease in labor force participation, female participation will be confronted with a serious fall back. Due to the free-market system, in the CME scenario large companies are still making (large) profits notwithstanding the unfavorable economic prospects. Therefore, only minor changes in labor force participation are expected in this scenario. 
The scenarios have been compiled using the multilevel scenario model MULTIPOLES developed by Kupiszewska and Kupiszewski (2005). MULTIPOLES is a cohort-component, hierarchical, multiregional, supra-national model of population dynamics. An important feature of MULTIPOLES is that the projections are prepared simultaneously for all countries included in the scenarios, instead of projecting the population for each country separately. Furthermore, the model is designed to facilitate the modeling of the impact of migration on population dynamics, by handling migration on three levels: interregional migration within each country (internal migration), interregional international migration between the countries in the model (in our scenarios the 27 Member States of the EU, the three EFTA states and Switzerland; intra-Europe migration), and international migration to and from the rest of the world (in our scenarios: extra-Europe migration). Finally, in addition to population modeling, with MULTIPOLES we can make projections of the labor force, taking into account future changes in labor force participation rates. A revised version of the model has been used in order to be able to use regional level input rates for all NUTS2 regions and all demographic components (Kupiszewski and Kupiszewska 2010). The scenarios have been compiled for 21 age groups (0-4 to 95-99 plus $100+)$ and nine 5-year periods covering the period 2005-2050.

\section{European Regional Populations: What are the Different Prospects?}

\subsection{Recent Trends}

The total population size of Europe is estimated to be around 507 million inhabitants in 2010 under all scenarios. ${ }^{5}$ In recent decades, the population has been increasing slowly. At the regional level, significant differences in population growth have occurred. Between 2000 and 2007, just over one out of four NUTS2 regions lost population, whereas nearly $60 \%$ of the regions experienced an average annual population growth of less than $1 \%$. In only one out of seven regions was population growth greater than $1 \%$ (Van der Erf et al. 2010). Migration has been the main source of regional population change. The impact of natural growth (the balance of births and deaths) has become very small. Relatively high population growth is mainly found in Western Europe and in several southern regions, while population decline is mainly found in Eastern Europe and in several regions in the north. The ageing of Europe's population is a long-running and continuing process. The percentage of regions with high shares of elderly people (more than $15 \%$ of the population aged 65 or over) increased from $60 \%$ in the 1990s to above $70 \%$ since 2000.

In the last decade, more than one-quarter of the NUTS2 regions had to face a decline in the size of the working-age population. These regions are located mainly in Germany (particularly the eastern Länder), the United Kingdom, Bulgaria, Hungary, Denmark, and Sweden (Fig. 1). On the other hand, many regions in the eastern part of Spain, the southern part of France, Ireland, and Poland still have

\footnotetext{
5 The population of the 31 countries involved in our study; based on projection forward from 2005 for the first time interval in the projection period.
} 


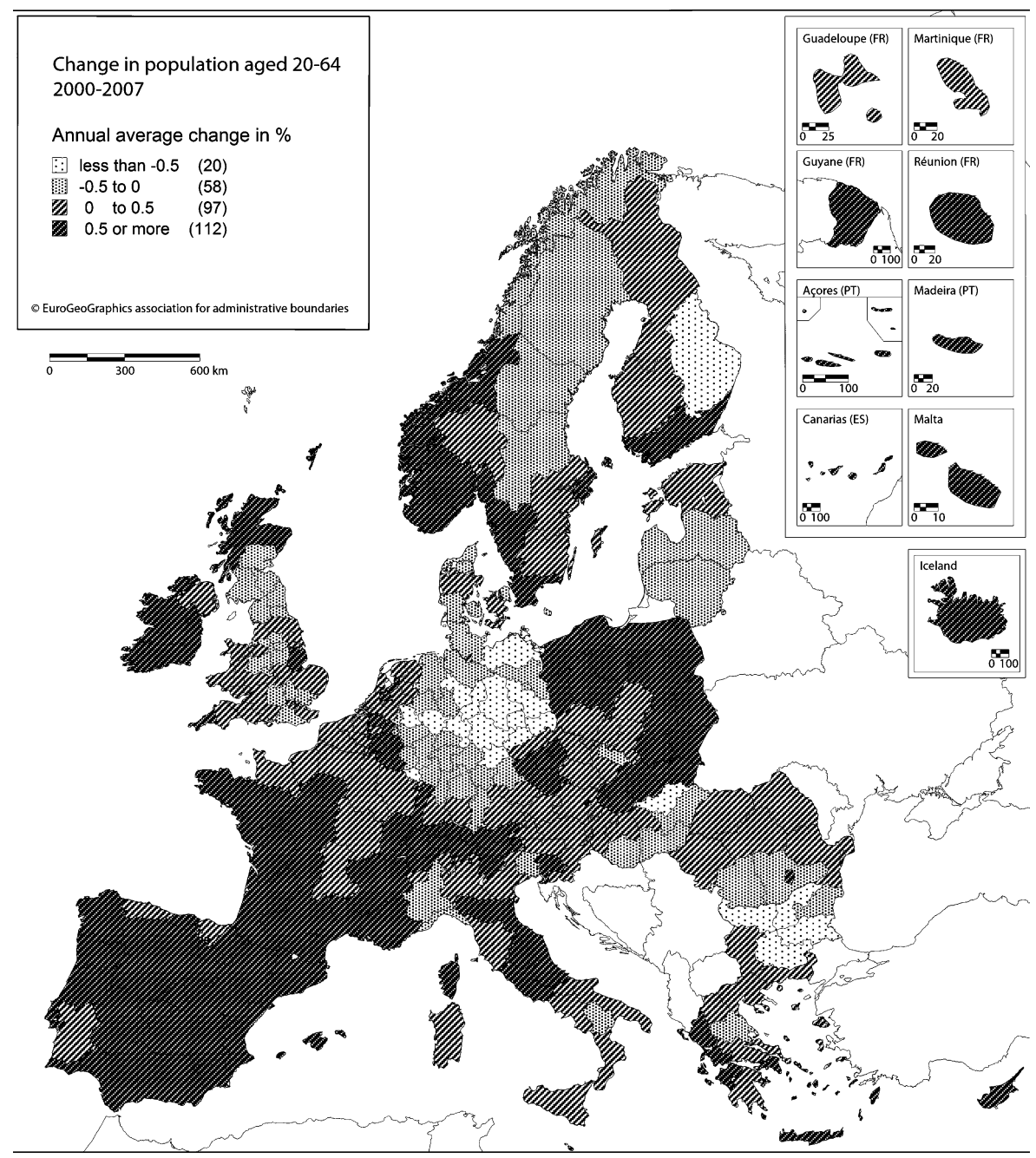

Fig. 1 Average annual percent change in working-age population, European regions (NUTS2) 2000-2007. Sources Van der Erf et al. (2010), ESPON (2011) and Eurostat (2011)

increasing working-age populations. In most regions, the main cause of changes in the size of the working-age population is cohort turnover, i.e., the replacement of the outflow of older generations retiring by the inflow of young generations entering the labor market. In $80 \%$ of the regions, the effect of cohort turnover on the size of the working-age population is still positive. Only in a small number of regions does the size of the working-age population increase despite negative cohort turnover (that is new cohorts entering the labor force are smaller than old cohorts leaving) because of compensating additions to the working-age population through positive net migration. Most of these regions can be found in Italy and Germany. In many 
Eastern European regions, the growth of the working-age population would have been greater, had not there been a steady stream of out-migrants.

\subsection{The Role of Migration in Population Development}

At the regional level, migration can be split into two components: internal migration between regions within each country and international migration from and to other countries (the sum of intra- and extra-Europe migration). In $73 \%$ of regions, the total migration balance was positive (Van der Erf et al. 2010). In about half of these regions, the impact of internal migration was negative, but these net outflows of migrants were compensated by a positive international migration balance. The reverse pattern, i.e., a negative international migration balance compensated by a positive internal migration balance, is rare. In $10 \%$ of the regions, both internal and international migration contributed to a negative net migration. These depopulation regions are found mainly in Bulgaria, Romania, and Poland.

A further distinction can be made between international migration to and from countries within and outside Europe. A negative international migration balance is almost exclusively the result of migration outflows to other countries within Europe. Almost all regions experience population growth due to immigration from outside of Europe. The directional mix of international migration varies between countries: countries whose main exchanges are with the world outside Europe (Czech Republic, France, Spain, UK), countries whose main exchanges are within Europe (Central Europe, Eastern Europe, and Nordic countries, except Sweden) and countries whose main emigration is to Europe and main immigration from outside Europe (Portugal, Italy, Greece, and Sweden). This pattern is related to former imperial history, to geographical position in the interior of Europe, or location on its Mediterranean littoral.

Without changes in the levels of fertility, mortality, and migration (the status quo scenario), the overall European population will fall by about 40 million by 2050 , which is a decline of about $8 \%$ (Kupiszewski and Kupiszewska 2010). Regional differences are considerable. Some $40 \%$ of the regions will experience population growth while $60 \%$ will be confronted with decline. In most of the cases, increasing populations are the result of net immigration from outside Europe. The main cause of population decline is negative natural change. Eleven regions, found in Romania, Bulgaria, Poland, and eastern Germany, would face a decline by over $50 \%$. In 86 other regions, population would decline by $20 \%$ or more. The overall impact of migration on population size is considerable. Three-quarters of all regions would have a larger population in 2050 if current migration flows continue than if there were to be no migration (Fig. 2).

The impact of migration (both internal and international) goes beyond the simple increase or decrease of population. It also affects the age structures of populations and the labor force. Without migration, in $70 \%$ of the regions in Europe the old age dependency ratio (ODR) would be higher. As most migrants are in the young-adult age group, their internal out-migration or international emigration raises the ODR as it reduces the number of working-age people. At the same time, in regions attracting migrants the newcomers will raise the number of young adults and the economically active population will increase. In general, migration is beneficial for most affluent 


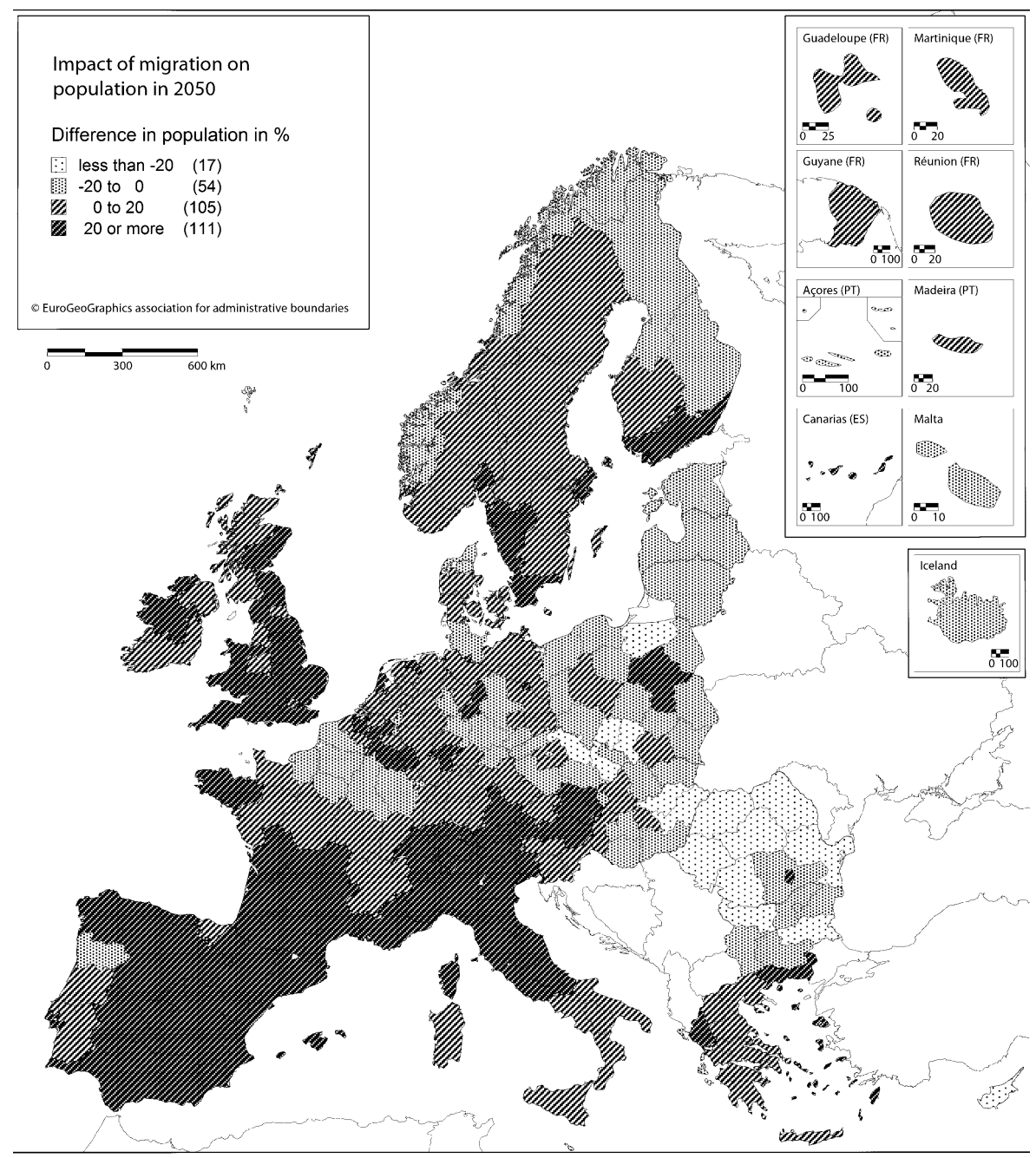

Fig. 2 The impact of migration on the populations of European regions (NUTS2) in 2050. Sources Kupiszewski and Kupiszewska (2010), ESPON (2011)

regions, whereas poor regions lose population due to migration. Migration therefore reduces ageing in affluent regions and increases it in poor ones and thus will be a strong factor increasing regional disparities.

\subsection{Implications of Different Policies}

In terms of total population, the main difference within the policy scenarios is between the "successful" and "unsuccessful" scenarios. Table 4 sets out some headline results from our scenario projections: total population, working-age population, the ODR, and the very old age dependency ratio (VODR) with their 
Table 4 Results for the four policy scenarios

\begin{tabular}{lrrrrr}
\hline Indicator & 2005 & \multicolumn{2}{l}{2050} & & \\
\cline { 3 - 5 } & & GSE & EME & \multicolumn{1}{l}{ LSE } & CME \\
\hline Total population (millions) & 503.5 & 592.5 & 604.7 & 502.4 & 500.0 \\
$\quad$ Change (\%) & & 17.7 & 20.1 & -0.2 & -0.7 \\
Population age 15-64 (millions) & 338.6 & 329.7 & 342.8 & 280.5 & 287.1 \\
$\quad$ Change (\%) & & -2.6 & 1.2 & -17.2 & -15.2 \\
ODR (Europe) & 22.4 & 57.9 & 53.2 & 58.1 & 55.0 \\
$\quad$ Standard deviation NUTS2 & 5.1 & 11.5 & 12.0 & 11.0 & 11.6 \\
VODR (Europe) & 14.0 & 47.5 & 42.2 & 49.6 & 43.9 \\
$\quad$ Standard deviation NUTS2 & 4.2 & 12.1 & 12.2 & 12.9 & 12.4 \\
\hline
\end{tabular}

$O D R$ old-age dependency ratio $=100 \times$ (population aged 65+/population aged $15-64)$, VODR very old age dependency ratio $=100 \times$ (population aged $75+/$ economically active population aged $15+$ )

standard deviations across the 287 NUTS regions. The GSE scenario produces the second highest population, but Europe experiences some losses in the working ages. The EME scenario projects the highest population and a slight increase in the working ages. Under the LSE and EME scenarios, total and working-age populations fall compared with 2005 levels. The ODR for Europe increases to 2050 by $2.4-2.6$ times, slightly more in the GSE and LSE scenarios than in the EME and CME. The standard deviation of ODR across regions more than doubles in the 45 years, more in the case of the market scenarios than the social scenarios. The VODR more than triples in the projection period, most in the LSE scenario and least in the EME scenario. The standard deviations also triple in the 2005-2050 period though the coefficients of variation (standard deviation/mean) do not change much.

Even though the social versus market orientation of policy appears not to make much difference to the overall outcome for Europe, there is a considerable difference in regional inequalities. The higher standard deviations in the regional ODRs for the market scenarios compared with the social scenarios are, of course, a product of our assumptions: what the projections do is to reveal the fuller implications of those assumptions. Natural increase is mildly positive in the GSE and EME projections but increasingly negative in the LSE and CME scenarios though not as negative as in the status quo scenario. The net migration is positive in all scenarios except for the CME where the European economy has become unattractive to immigrants and many have returned to their emerging country economies, which are experiencing much better growth (the pattern of the last two decades). However, the EME and GSE assume much higher levels of immigration to supply the labor needs of successful Europe. Under the EME scenario, the net immigration rises to circa 4.8 per thousand population. This level will require Europe to commit to be a world region that welcomes and integrates its immigrant population in a more positive way than at present.

Under the status quo scenario, the majority of regions in Central and Eastern Europe as well as in Germany, Northern France, Northern Scandinavia, Greece, Southern Italy, North and West Spain, and Portugal will lose population. Most of the 
rest of Western Europe will experience small population gains. In the EME scenario, the population in most regions in Scandinavia, the British Isles, France, North and Central Italy, and South and East Spain will grow by more than $25 \%$ between 2005 and 2050. Most of the former Iron Curtain regions are projected to lose population but in the capital city regions of Warsaw, Prague, Budapest, and Bucharest, this loss is small. The regions of Western Germany, parts of Northern France, and Western Spain fall in the small (0 to $-25 \%)$ class. The GSE map is a smoothing of the EME map with fewer regions in the top or bottom classes and thus represents a gain in terms of cohesion. In the CME scenario the majority of regions show losses in population while the LSE scenario shrinks the variation so that there are fewer regions in the highest loss category (less than $-50 \%$ ).

If labor force participation rates do not change, the size of the labor force in Europe will decline by $17 \%$ by 2050 (Rees et al. 2010b). In 23 regions, the labor force would shrink by more than $50 \%$. Only in one-quarter of the regions would the labor force increase. In $90 \%$ of the European regions, the labor force would be smaller without extra-European migration. In all European regions, the ratio of the inactive to the active population would be higher without extra-European migration. Extra-European migration would have a beneficial, albeit unequal, impact on the balance between the labor force and economically inactive population.

Only if activity rates increase and if extra-European migration is high, will the total size of the labor force in Europe increase to 2050. However, even under favorable conditions in the GSE and EME scenarios, 35-40 \% of the regions will face a decline in the size of the labor force (Fig. 3). If economic conditions are poor as under the LSE and CME scenarios, activity rates will not increase and immigration will be low. In that case, 55-70\% of the regions will experience a decline of the labor force by $10 \%$ or more. In most regions in eastern and southern parts of Europe, the labor force may decrease by more than $30 \%$. Also, many regions in Germany and Austria will have to cope with similar losses of labor supply. Market-oriented policies combined with high economic growth (the EME scenario) would result in a substantially growing labor force in many regions in the western and northern part of Europe. However, the contrast with the eastern part is sharp, where a majority of the regions will have an enduring shrinking labor force. If policies focus on regional cohesion the contrast between regions with a severe decline of the labor force and those with a steep growth is smaller.

Although the size of the labor force continues to grow if labor force participation rates increase, the rate of growth will slow due to the decline in the size of the working-age population. This implies that an increase in labor productivity will have to become the main driver of economic growth. According to the Lisbon strategy, policies should not just aim to improve capital investment, but should also include investment in human capital, training, and capacity building. The Europe 2020 strategy asserts that labor productivity should be raised through a focus on new skills and jobs. The scenarios show that if productivity does not improve, there is the risk that growth in GDP per capita will become negative.

Even if life expectancy does not increase, the population aged 65+ in the European area would increase by $40 \%$ to 2050 (Kupiszewski and Kupiszewska 2010). If life expectancy continues to grow, the number of persons aged $65+$ will increase by 


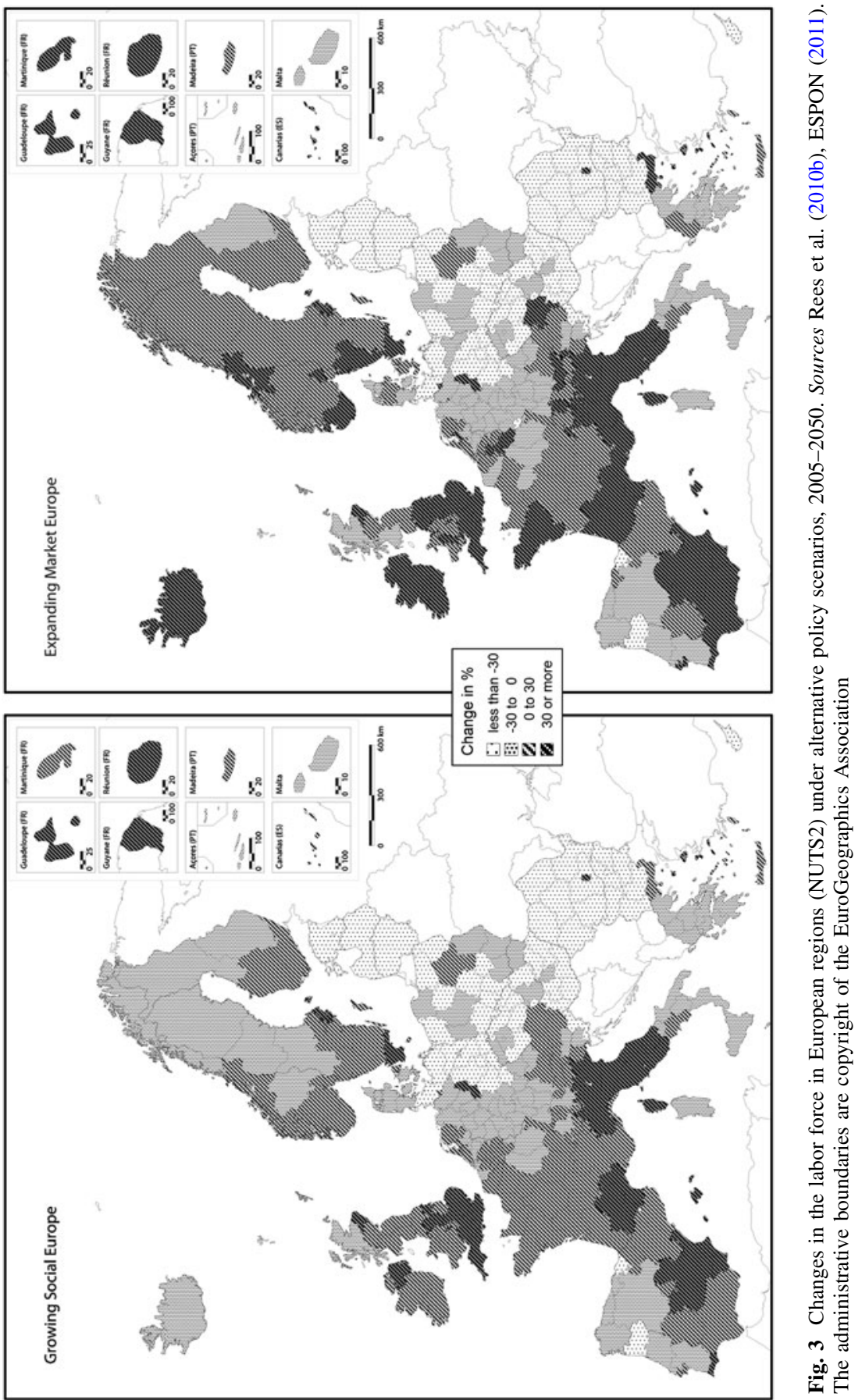




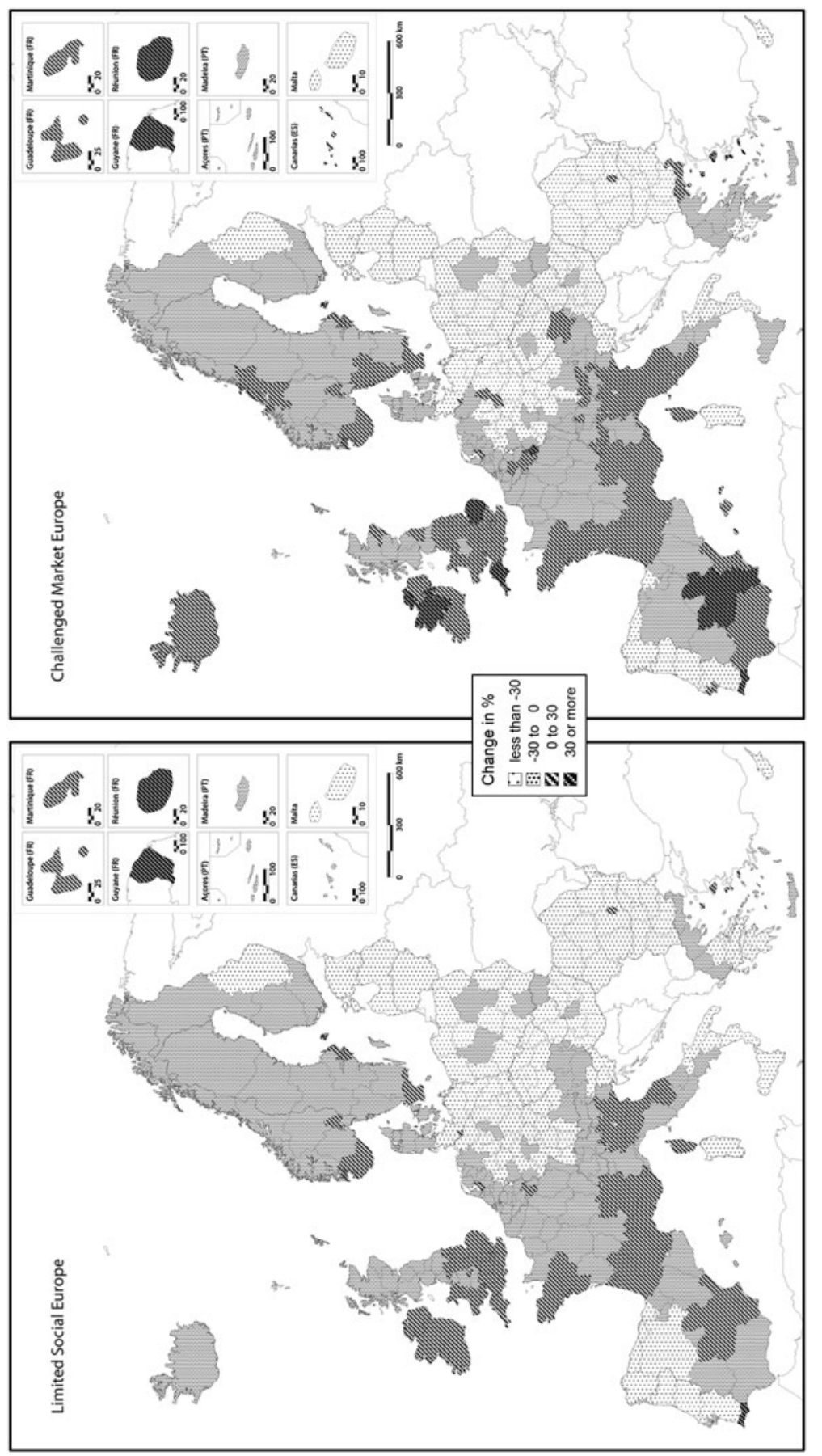

م. 


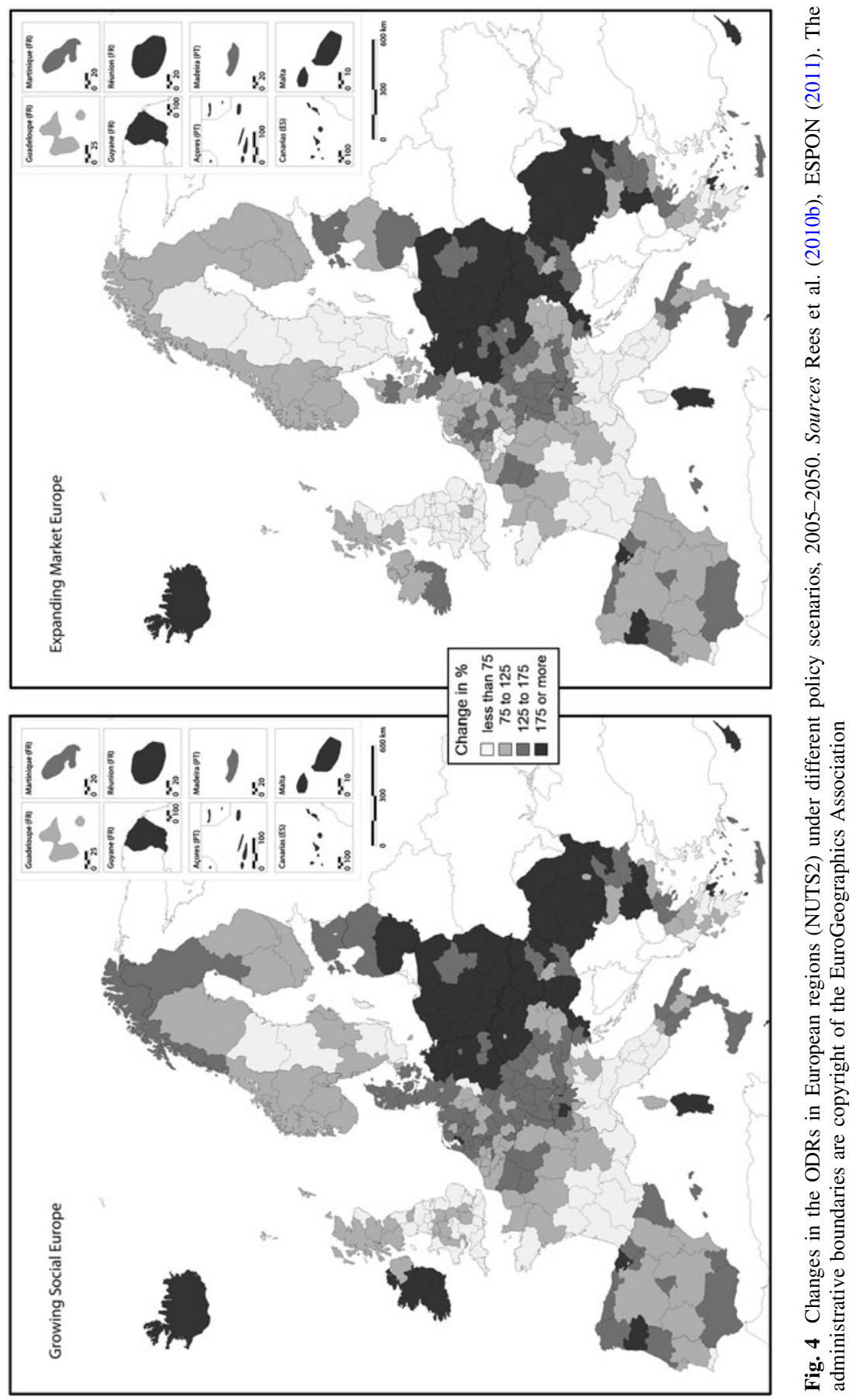




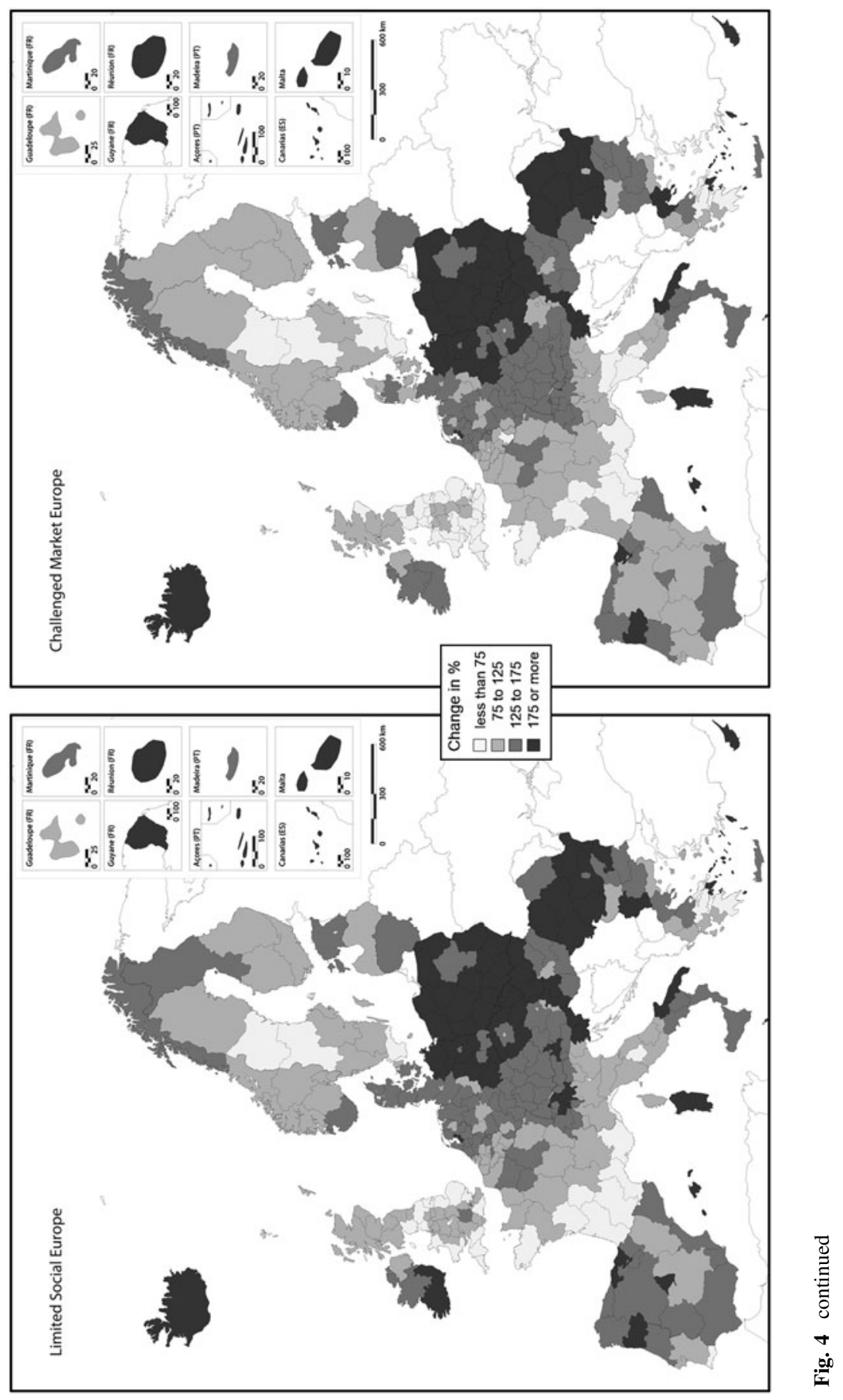


87-111\% (Rees et al. 2010b). The effects of policies affecting the levels of fertility and migration on the rate of ageing are limited. The differences in the ageing process do not vary much between the different scenarios. The share of persons aged $65+$ in the total population in 2050 will vary between 29 or $32 \%$ depending on the levels of fertility, life expectancy, and migration. When we look at the ratio of older people to people in the working ages (the old-age dependency ratio or ODR), however, we see that the potential changes are truly huge (Fig. 4). No regions in Europe under any of the policy scenarios are likely to see a decrease in the ODR and substantial numbers of regions in Central and Eastern Europe will see an increase in ODR of $200 \%$ or more, reflecting in part the lower share of their current population aged $65+$. However, in the western, northern, and southern regions, increases of 50-200\% will occur, irrespective of policy scenario. Even more dramatic will be increases in the VODRs.

\section{Discussion and Conclusions}

\subsection{What Our Analyses Suggest}

If current demographic trends and migration flows continue, the European workingage population will shrink and disparities across regions will increase. This has led to calls for policies to improve European competitiveness and regional cohesion. Policies may be aimed to accommodate these demographic changes or policies may be aimed to directly affect the demographic trends. Growth cannot simply be enhanced and disparities cannot simply be reduced by policies aimed at directly affecting demographic developments and migration flows since these depend on the economic situation.

If young couples do not have faith in the future they tend to have only a small number of children. Therefore, policies aiming to raise the level of fertility will not be effective if the general economic situation fails to improve. Moreover, policies affecting the level of fertility will have effects on the growth of the working-age population in the long run only. These policies will not help in reducing labor shortages in the next two decades or so.

Policies aimed at increasing mobility between European regions and countries may reduce rather than increase cohesion since young adults tend to migrate from disadvantaged to affluent regions. Thus policies aimed to stimulate migration can be effective only if they are part of policy bundles aimed to improve living conditions in poor regions, for example by improving the availability of jobs, housing, schools, and the quality of the environment. Policies that are aimed at allowing economic migration from outside Europe in order to meet the needs of the labor market will be effective only if integration policies are successful. Furthermore, as migrants tend to move to economically healthy regions, regional disparities may increase, particularly as regions with a healthy economy tend to be better able to attract higherskilled migrants. Policies to address demographic challenges should therefore not just be aimed to affect the size and direction of demographic trends and migration flows, but should be combined with policies in other spheres as well. 


\subsection{Is Population Decline Good Or Bad?}

There exists a debate about whether population decline is good or bad for countries and regions (Reher 2007; Coleman and Rowthorn 2011; Van Dalen and Henkens 2011). The arguments pointing to the benefits of population decline include reduction of environmental impact, greater sustainability, reduction of greenhouse gas emissions, lowering of traffic congestion, and release of more housing space for improving living standards. Regional landscapes can be improved and forests can be regenerated. The lament "How green was my valley" (Llewelyn 1939) applied to the devastation that occurred as the South Wales coalfield was developed from 1850 to 1914 , became "Green, Green My Valley Now" (Llewelyn 1975) as all the deep mines closed, the spoil heaps were flattened, and the waste land replanted with trees. However, the region still remains one of poorest in the UK.

The case against regarding population decline as beneficial is mainly economic. As economic activity declines, regional markets shrink, investment by business is discouraged, firms fail to innovate and a downward spiral of economic activity occurs (Myrdal 1957) and regional competitiveness is lost. The key to reducing environmental impact is technical innovation and planning regulations that protect the environment. Money incomes decline (balanced against some quality of life improvements) and the smartest and most active people migrate out of declining regions in a process that reinforces the outflows. The people left behind are the poorest and most dependent on transfers (subsidies, benefits, remittances). To date, the European Commission has viewed any population decline as unsatisfactory and sought to design policies to turn decline around or to provide some compensation (CEC 2008a, b). If the jobs are created the people will come. The difficulty of creating jobs in the most deprived regions should not be under-estimated. Relative population decline will mean a shift of people to more prosperous regions.

\subsection{The Policy Response to Ageing}

All scenarios show significant increases in old age and labor market dependency ratios. The direction that policy must take is clear: we must decrease the numbers of dependent old and increase the numbers of non-dependent working-age adults. This should be achieved through raising the age of entitlement to state pension, reducing those entitlements through generating benefits through savings rather than tax transfers, ensuring healthy ageing that leaves people well enough to work well beyond current retirement ages and planning new career and work patterns that enable older workers to downshift in terms of physical effort, responsibility, or working hours. There has been and will be vigorous opposition to such measures by workers who currently enjoy the benefits of the current system but the privileges of "system insiders" will threaten social solidarity while the numbers outside the system grow. In the debate about these needed reforms to our system of social support in old age, there is a contention that older workers working beyond current retirement age will take up jobs that would otherwise have become available for younger workers. However, our projections show that the population of working age will fall in most regions under most scenarios. There will therefore be plenty of 
opportunities for young-adult workers who have the skills needed in today's labor market and for the retention of older workers who can adapt to changing labor market conditions by acquiring new skills and adjusting their hours of work to suit their capacities. In fact, the most effective and productive working teams are intergenerational, benefiting from the energy of youth and the wisdom of age but in organizations that are less hierarchical and more democratic.

Policies aimed at affecting the size of the labor force should be supplemented by policies aimed to affect productivity growth through investment in human capital. If the labor force declines, productivity growth will need to become the main driver of economic growth.

\subsection{The Pros and Cons of International and Interregional Migration}

The pattern of regional population decline and population loss goes hand in hand with poorer regions exporting people to richer regions. This has benefits for both kinds of regions. Surplus labor in poorer regions transfers to where it can be productive and earn a living. Labor shortages in richer regions are relieved and regional product enhanced. The net welfare of Europe is improved as a result of the process, but we continue to worry that poorer regions are somehow subsidizing the richer regions by investing in the education and training of young people and then seeing that investment move elsewhere. Earlier we suggested that inter-country and inter-region migration would lead to increasing inequality between regions. How can this process coincide with a claim that migration processes improve the net welfare of the European population? If we measure regional inequality using the regional mean values of welfare indicators (e.g., per capita income), then the gap between rich and poor regions will remain, but the number of people who have moved out of poverty through migration will be large. Using people as the observation units rather than regions measures inequality more fairly.

Recent work makes the case that migration benefits the sending country as well as the receiving country (Goldin et al. 2011). The main arguments are that remittances make a contribution to sending country income that is huge (much much larger than aid flows), that the prospect of emigration opportunities encourage sending country populations to invest more in education and that the productivity of the fraction of emigrants who return is higher than that of stayers. Emigration also connects poor regions with wider international networks and this benefits business development in sending regions. Kapur (2010) argues that Indian engineers and IT specialists who migrated to Silicon Valley, California were instrumental in getting the world to buy services from South India's IT firms. The main focus of these studies has been on intercontinental migrants rather than intra-Europe or intra-country migrants. Turning around the economies and therefore populations of declining regions is enormously difficult. Even the vast fiscal transfers from the Federal German Government to the eastern Länder of Germany has not enabled those states to catch up with the western Länder. We should not therefore expect too much from policy initiatives but be grateful that the existence of the right to migrate across all Europe means that people can move to where they can be most productive. 


\subsection{Final Remarks}

In this paper, we have described the variation across Europe's regions of the demographic trends of population decline/growth, and the contributions of natural increase, intra-national, intra-Europe, and extra-Europe migration to the trends. We have shown how a continuation of those trends will lead to substantial population losses in a majority of regions and to demographic ageing that will be much more extreme than hitherto experienced in all regions. As older populations expand, the labor force ages shrink in size in most regions. We considered policy scenarios that might mitigate those trends or alter them. In two of those policy scenarios, where Europe is not successful in solving current economic and environmental challenges, the population is maintained around current levels for Europe as a whole because of anticipated and continued improvements in survival to older ages. We project that if Europe successfully meets those challenges, its population overall might rise by $20 \%$ to mid-century, though this would not prevent a further decline in Europe's share of world population from 7 to around $5 \%$. Marked regional differences are likely to persist even when we assume some convergence in demographic trends.

Our projections are based on assumptions that reflect economic, environmental, and social trends and the potential impact of policies associated with each scenario. We would not claim that any of the scenarios are more or less likely and so none of them is a forecast. However, recent events such as the ongoing economic crisis along with substantial resistance to cuts in social transfers suggests that the LSE scenario comes close to 2011 economic conditions and welfare policies.

Acknowledgments This paper reports on the findings of the Applied Research project 2013/1/3, Demographic and Migratory Flows affecting European Regions and Cities (DEMIFER), conducted within the framework and with the financial support of the ESPON 2013 Programme, partly financed by the European Regional Development Fund. The partnership supporting the ESPON Programme consists of the EU Commission and the Member States of the EU27, plus Iceland, Liechtenstein, Norway and Switzerland. This paper does not necessarily reflect the opinion of the members of the Monitoring Committee. Copies of the Final Report (De Beer et al. 2010a) and Annexes may be downloaded from the ESPON programme website at http://www.espon.eu/main/Menu_Projects/Menu_AppliedResearch/ demifer.html. The authors are very grateful to their colleagues in the DEMIFER project team for helping produce the work upon which this paper is based. Team members were: at the Netherlands Interdisciplinary Demographic Institute (NIDI), Rob Van der Erf; at the University of Vienna, Ramon Bauer and Heinz Fassmann; at the International Organization for Migration/Central European Forum for Migration and Population Research, Dorota Kupiszewska and Marek Kupiszewski; at the University of Leeds, Peter Boden, Adam Dennett, John Stillwell, Pia Wohland and Martyna Jasinska; at the Netherlands Environmental Assessment Agency, Andries De Jong and Mark Ter Veer; at the Nordic Centre for Spatial Development, Johanna Roto, Lisa Van Well and Daniel Rauhut; at the National Research Council, Institute for Research on Population and Social Policies, Corrado Bonifazi, Massimiliano Crisci and Giuseppe Gesano. Further colleagues contributed to the case studies undertaken in the project. In finalizing this paper, the authors were assisted by Corina Huisman of NIDI who transformed the original colored maps into black and white. Their help and the constructive comments of two anonymous reviewers are gratefully acknowledged.

\section{References}

Barca, F. (2009). An agenda for a reformed cohesion policy; a place-based approach to meeting European Union challenges and expectations. Independent Report prepared at the request of D. 
Hübner, Commissioner for Regional Policy. Retrieved January 2012, from http://www.euterritorial-agenda.eu/Related\%20Documents/report_barca_v0605.pdf.

CEC. (1973). Report on the regional problems in the enlarged community. COM(73) 550 final. Brussels: Commission of the European Communities.

CEC. (2005). Green Paper confronting demographic change: a new solidarity between the generations. COM(2005) 94 final. Brussels: Commission of the European Communities. Retrieved March 16, 2005, from http://europa.eu/legislation_summaries/employment_and_social_policy/situation_in_ europe/c10128_en.htm.

CEC. (2008a). Green Paper on Territorial Cohesion-turning territorial diversity into strength. Brussels: Commission of the European Communities. Retrieved January 2010, from http://ec.europa. eu/regional_policy/consultation/terco/index_en.htm.

CEC. (2008b). Regions 2020 - an assessment of future challenges for EU regions. Brussels: Commission of the European Communities. Retrieved January 2010, from http://ec.europa.eu/regional_ policy/sources/docoffic/working/regions2020/index_en.htm.

Coleman, D., \& Rowthorn, R. (2011). Who's afraid of population decline? A critical examination of its consequences. In R. D. Lee \& D. S. Reher (Eds.), Demographic transition and its consequences. A supplement to Population and Development Review, 37, 217-248.

Commission on Social Determinants of Health. (2008). CDSH final report: Closing the gap in a generation: Health equity through action on the social determinants of health. Geneva: World Health Organization. Retrieved May 2011, from http://www.who.int/social_determinants/ thecommission/finalreport/en/index.html.

Datta Gupta, N., Smith, N., \& Verner, M. (2008). The impact of Nordic countries' family friendly policies on employment, wages, and children. Perspective article. Review of Economics of the Household, 6, 65-89.

De Beer, J., Van der Gaag, N., Van der Erf, R., Bauer, R., Fassmann, H., Kupiszewska, D., Kupiszewski, M., Rees, P., Boden, P., Dennett, A., Jasińska, M., Stillwell, J., Wohland, P., De Jong, A., Ter Veer, A., Roto, J., Van Well, L., Heins, F., Bonifazi, C., \& Gesano, G. (2010a). Final report DEMIFER demographic and migratory flows affecting European regions and cities. The ESPON 2013 Programme. Applied Research Project 2013/1/3. Retrieved January 2011, from http://www.espon. eu/main/Menu_Projects/Menu_AppliedResearch/demifer.html.

De Beer, J., Raymer, J., Van der Erf, R., \& Van Wissen, L. (2010b). Overcoming the problems of inconsistent international migration data: A new method applied to flows in Europe. European Journal of Population, 26, 459-481.

Doll, R., Peto, R., Boreham, J., \& Sutherland, I. (2004). Mortality in relation to smoking: 50 Years' observations on male British doctors. British Medical Journal. doi:10.1136/bmj.38142.554479.AE.

Engelhardt, H., Kögel, T., \& Prskawetz, A. (2004). Fertility and female employment reconsidered: A macro-level time series analysis for developed countries, 1960-2000. Population Studies, 58(1), 109-120.

ESPON. (2011). ESPON Database 2013. Retrieved May 2011, from http://www.espon. eu/main/Menu_Projects/Menu_ScientificPlatform/espondatabase2013.html.

European Commission, Education and Training. (2011). The Lifelong Learning Programme: Education and training opportunities for all. Retrieved September 2011, from http://ec.europa.eu/ education/lifelong-learning-programme/doc78_en.htm.

European Commission, Home Affairs. (2011). Background to the Schengen cooperation. Retrieved September 2011, from http://ec.europa.eu/home-affairs/policies/borders/borders_schengen_en.htm.

European Commission, Research and Innovation. (2011). Welcome to the Marie Curie actions: Career opportunities for researchers. Retrieved September 2011, from http://ec.europa.eu/research/ mariecurieactions/.

Eurostat. (2008). NUTS—nomenclature of territorial units for statistics. Retrieved May 2011, from http://epp.eurostat.ec.europa.eu/portal/page/portal/nuts_nomenclature/introduction.

Eurostat. (2011). Statistics. Retrieved May 2011, from http://epp.eurostat.ec.europa.eu/portal/ page/portal/statistics/themes.

Giannakouris, K. (2008). Ageing characterises the demographic perspectives of the European societies. Statistics in Focus, 72/2008. Luxembourg: Publications Office of the European Union.

Giannakouris, K. (2010). Regional population projections EUROPOP2008: Most EU regions face older population profile in 2030. Statistics in Focus, 1/2010. Luxembourg: Publications Office of the European Union. 
Goldin, I., Cameron, G., \& Balarajan, M. (2011). Exceptional people: How migration shaped our world and will define our future. Princeton, NJ: Princeton University Press.

HMD. (2009). The human mortality database. Berkeley, CA: University of California. http://www.mortality.org/.

Howe, N., \& Jackson, R. (2005). Projecting immigration. A survey of the current state of practice and theory. A report of the CSIS global aging initiative. Washington, DC: Center for Strategic and International Studies.

Jaumotte, F. (2004). Labour force participation of women: Empirical evidence on the role of policy and other determinants in OECD countries. OECD Economic Studies, 37(2003/2). http://www.oecd.org/ dataoecd/12/39/34562935.pdf.

Jennissen, R. (2004). Macro-economic determinants of international migration in Europe. Amsterdam: Dutch University Press.

Kapur, D. (2010). Diaspora, democracy and development. Princeton, NJ: Princeton University Press.

Kohler, H. P., Billari, F. C., \& Ortega, J. A. (2006). Low fertility in Europe: Causes, implications and policy options. In F. R. Harris (Ed.), The baby bust: Who will do the work? Who will pay the taxes? (pp. 48-109). Lanham, MD: Rowman and Littlefield Publishers.

Kravdal, O. (2002). The impact of individual and aggregate unemployment on fertility in Norway. Demographic Research, 6(10), 261-293.

Kupiszewska, D., \& Kupiszewski, M. (2005). A revision of the traditional multiregional model to better capture international migration: The MULTIPOLES model and its applications. CEFMR Working Paper 10/2005.

Kupiszewski, M., \& Kupiszewska, D. (2010). Reference scenarios. Final Report DEMIFER, Annex 5, The ESPON 2013 Programme, Applied Research Project 2013/1/3. Retrieved January 2011, from http://www.espon.eu/main/Menu_Projects/Menu_AppliedResearch/demifer.html.

Lanzieri, G. (2009). EUROPOP2008: A set of population projections for the European Union. Paper presented at the XXVI IUSSP International Population Conference, Marrakech, 27 September-2 October 2009.

Lanzieri, G. (2010). Is fertility converging across the Member States of the European Union? doi: $10.2785 / 50697$.

Lanzieri, G. (2011). The greying of the baby boomers, a century-long view of ageing in European populations. Statistics in Focus, 23/2011. Luxembourg: Publications Office of the European Union.

Llewelyn, R. (1939). How green was my valley. London: Michael Joseph.

Llewelyn, R. (1975). Green green my valley now. London: Michael Joseph.

Massey, D. S., Arango, J., Hugo, G., Kouaouci, A., Pellegrino, A., \& Taylor, J. E. (1993). Theories of international migration: A review and appraisal. Population and Development Review, 20, 699-751.

McPherson, K., Marsh, T., \& Brown, M. (2009). Tackling obesities: Future choices-modelling future trends in obesity and the impact on health. Report of Government Office for Science (2nd ed.). Retrieved September 2011, from http://www.foresight.gov.uk/OurWork/ActiveProjects/Obesity/ KeyInfo/Index.asp.

Ministers Responsible for Territorial Development. (2007). Territorial agenda for the European Union, 2007-2010: Towards a more competitive Europe of diverse regions. Agreed on the occasion of the Informal Ministerial Meeting on Urban Development and Territorial Cohesion in Leipzig on 24/25 May 2007. Retrieved January 2010, from http://www.eu-territorial-agenda.eu/Reference \%20Documents/Territorial-Agenda-of-the-European-Union-Agreed-on-25-May-2007.pdf.

Myrdal, G. (1957). Economic theory and under-developed regions. London: Duckworth.

Neyer, G., \& Andersson, G. (2008). Consequences of family policies on childbearing behavior: Effects or artifacts? Population and Development Review, 34(4), 699-724.

ONS. (2008). National population projections, 2006-based. Series PP2 No 26. Basingstoke: Palgrave Macmillan, Office for National Statistics. Retrieved March 2009, from http://www.statistics. gov.uk/downloads/theme_population/pp2no26.pdf.

Prommer, I., \& Wilson, C. (2006). An analytical summary of the current practices of definition of assumption making in population projections. Deliverable D14 of the MicMac project: Bridging the micro-macro gap in population forecasting. EU Contract no. SP23-CT-2005-006637. Retrieved March 2009, from http://www.nidi.knaw.nl/en/micmac/publications/.

Raymer, J., De Beer, J., \& Van der Erf, R. (2011). Putting the pieces of the puzzle together: Age and sexspecific estimates of migration amongst countries in the EU/EFTA, 2002-2007. European Journal of Population, 27, 185-215. 
Rees, P., Boden, P., Dennett, A., Stillwell, J., Jasinska, M., de Jong, A., \& Ter Veer, M. (2010a). Report on scenarios and a database of scenario drivers. Final Report DEMIFER, Annex 6, The ESPON 2013 Programme, Applied Research Project 2013/1/3. Retrieved January 2011, from http://www.espon.eu/main/Menu_Projects/Menu_AppliedResearch/demifer.html.

Rees, P., Boden, P., Dennett, A., Stillwell, J., Jasinska, M., de Jong, A., Ter Veer, M., Kupiszewski, M., \& Kupiszewska, D. (2010b). Regional population dynamics: A report assessing the effects of demographic developments on regional competitiveness and cohesion. Final Report DEMIFER, Annex 7, The ESPON 2013 Programme, Applied Research Project 2013/1/3. Retrieved January 2011, from http://www.espon.eu/main/Menu_Projects/Menu_AppliedResearch/demifer.html.

Reher, D. S. (2007). Towards long-term population decline: A discussion of relevant issues. European Journal of Population, 23, 189-207.

Rønsen, M. (2004). Fertility and public policies-evidence from Norway and Finland. Demographic Research, 10(6), 143-170.

Rowan, S., \& Wright, E. (2010). Developing stochastic population forecasts for the United Kingdom: Progress report and plans for future work. Paper presented at the Joint Eurostat/UNECE Work Session on Demographic Projections, 28-30 April 2010, Lisbon, Portugal. http://www.unece. org/fileadmin/DAM/stats/documents/ece/ces/ge.11/2010/wp.40.e.pdf.

Shaw, C. (2008). The National Population Projections Expert Advisory Group: Results from a questionnaire about future trends in fertility, mortality and migration. Population Trends, 134, 42-53.

Sobotka, T. (2004). Is lowest-low fertility in Europe explained by the postponement of childbearing? Population and Development Review, 30, 195-220.

The Marmot Review. (2010). Fair society, healthy lives. The Marmot Review. Strategic review of health priorities in England post-2010. Retrieved May 2011, from http://www.ucl.ac.uk/marmotreview.

Tromans, N., Jefferies, J., \& Natamba, E. (2009). Have women born outside the UK driven the rise in UK births since 2001? Population Trends, 136, 28-42.

Van Dalen, H. P., \& Henkens, K. (2011). Who fears and who welcomes population decline? Demographic Research, 25(13), 437-464.

Van der Erf, R., De Beer, J., \& Van der Gaag, N. (2010). Report on effects of demographic and migratory flows on European regions. Final Report DEMIFER, Annex 1, The ESPON 2013 Programme, Applied Research Project 2013/1/3. Retrieved January 2011, from http://www.espon.eu/ main/Menu_Projects/Menu_AppliedResearch/demifer.html. 